Volume 15. Nomor 1. June 2020 Page 53-63
Pandecta
http://journal.unnes.ac.id/nju/index.php/pandecta

\title{
Pencegahan Korupsi Melalui Pencabutan Hak Politik : Sebuah Telaah dari Perspektif Pembaruan Hukum Pidana Indonesia
}

\author{
Yaris Adhial Fajrin ${ }^{1}$, Ach. Faisol Triwijaya ${ }^{2}$ \\ ${ }^{1}$ Fakultas Hukum, Universitas Muhammadiyah Malang, Malang, Indonesia \\ ${ }^{2}$ Magister Ilmu Hukum, Universitas Brawijaya, Indonesia \\ DOI: http://dx.doi.org/10.15294/pandecta.v15i1.18744
}

\begin{abstract}
Article info
Abstrak

Article History:

Received : April 92019

Accepted: May 292020

Published: June 152020

Tindak pidana korupsi banyak terjadi akibat penyalahgunaan kekuasaan yang dilakukan oleh pejabat publik, diantaranya kepala daerah Upaya pemberantasan korupsi banyak dilakukan dengan preventif dan represif. Salah satu upaya preventif yang dilakukan adalah dengan memberikan larangan mantan terpidana mencalon-

Keywords:

korupsi; pencegahan:

pencabutan hak politik

kan diri dalam kontes pemilihan umum yang tujuannya untuk mencari pemimpin yang berkualitas. Namun pasca putusan MK Nomor 71/PUU-XIV/2016 mennggambarkan penurunan atau pelemahan pencegahan korupsi di Indonesia. Penulisan ini bertujuan untuk menemkan dasar akademis pentingnya pencegahan korupsi melalui corruption; corruption prevention; revocation politic right pembatasan sesorang mencalonkan diri dalam jabatan publik. Diperoleh kesimpulan dari penelitian ini yaitu Putusan MK tersebut membuka peluang bagi mantan terpidana korupsi untuk mencalonkan diri. Sehingga sanksi pencabutan hak politik bagi terpidana korupsi yang menjalani sanksi penjara di bawah lima tahun perlu diprioritaskan untuk dijatuhkan. Sinergitas antara dua mekanisme tersebut, diperlukan guna mewujudkan cita-cita pemerintahan yang baik dan bersih, yang berkeadilan sosial.
\end{abstract}

\begin{abstract}
Corruption crimes occurred due to the misuse of power carried out by public officials, among them the regional head of anti-corruption efforts are carried out with preventive and repressive. One of the preventive efforts undertaken is to provide a former criminal ban to run for a general election contest whose goal is to find a qualified leader. However, after the decision of MK No. 71/PUU-XIV/2016, he described the decline or weakening of corruption prevention in Indonesia. This writing aims to accompany the academic basis of the importance of the prevention of corruption through the restriction of a person running in public office. Derived by the conclusion of this research, the COURT award opens an opportunity for former convicted corruption to run. Thus, the sanction of political Rights for criminal corruption under five years of imprisonment must be prioritized to be dropped. Synergity between the two mechanisms, necessary to realize the ideals of good and clean government, the social justice.
\end{abstract}




\section{Latar Belakang}

Angka korupsi di Indonesia menujukkan kenyataan bahwa tindak pidana tersebut masih menjadi ancaman bagi keberlangsungan Negara Indonesia. Tahun 2018 Indeks perepsi korupsi Indonesia berada pada angka 40 lebih baik dari tahun sebelumnya pada angka 38 (Mashabi, 2020). Angka ini masih jauh dari harapan Indonesia yang bebas dari korupsi. Pada ruang lingkup ASEAN, Indonesia menempati urutan ke empat di bawah Singapura, Brunei Darussalam, dan Malaysia. Pada lingkup yang lebih luas, Indonesia menempati urutan ke-89 dari 180 negara. Kerugian negara yang ditimbulkan dari korupsi menurut rilis Indonesia Corruption Watch, tahun 2018 mencapai 9,29 triliyun rupiah, sedangkan yang berhasil dikembalikan (aset recovery) dari tahun 2014 sampai dengan 2018 hanya sekitar 1,6 triliyun rupiah (Fadhil, 2019). Kenyataan yang demikian menjadi warning bagi pemerintah beserta pihak terkait untuk lebih giat untuk melakukan penindakan sekaligus pencegahan korupsi. Sebab korupsi secara langsung maupun tidak langsung memberikan dampak terhadap banyak sektor-sektor kehidupan. Kerugian langsung maksudnya adalah kerugian akibat korupsi yang dapat dirasakan pada saat itu juga, semisal kerugian keuangan negara. Sedangkan yang dimaksud dengan kerugian tidak langsung adalah ketika kerugian akibat korupsi tersebut masih perlu menunggu beberapa waktu setelah terjadinya suatu korupsi. Kerugian yang bersifat langsung dan tidak langsung akan berpengaruh terhadap ruginya keuangan negara atau berkurangnya keuangan negara yang tentunya negara akan mengalami suatu kerugian (Damanik, 2016)

Angka indeks persepsi korupsi dan angka kerugian negara yang relatif tinggi, menunjukkan bahwa korupsi masih tumbuh subur layaknya hantu yang menakutkan bagi kehidupan bernegara. Ketakutan tersebut wajar mengingat korupsi sebagai salah satu extra ordinary crime berdampak kepada tidak maksimalnya sendi-sendi kehidupan dan pola masyarakat. Apalagi korupsi di masa otonomi daerah (mulai diterapkan di Indonesia sejak tahun 1999 melalui Undang-Undang No- mor 22 Tahun 1999 tentang Pemerintahan Daerah) banyak melibatkan kepala daerah dalam kasus korupsi. Data menunjukkan sejak tahun 2004 hingga tahun 2019 kepala daerah yang terjerat kasus korupsi sebanyak 122 orang dengan rincian Gubernur sebanyak 21 orang dan Bupati/Wali kota sebanyak 201 orang (Jayani, 2019).

Regulasi telah dikeluarkan oleh pemerintah bersama Dewan Permusyawaratan Rakyat (DPR) melalui sejumlah peraturan perundang-undangan mengenai pemilihan kepala daerah. Terakhir adalah Undang-Undang Nomor 10 Tahun 2016 tentang Perubahan Kedua Atas Undang-Undang Nomor 1 Tahun 2015 Tentang Penetapan Peraturan Pemerintah Pengganti Undang-Undang Nomor 1 Tahun 2014 Tentang Pemilihan Gubernur, Bupati, Dan Walikota Menjadi UndangUndang (yang selanjutnya disebut dengan Undang-undang No. 10 Tahun 2016). Undang-undang No. 10 Tahun 2016 memberikan persyaratan kepada bakal calon kepala daerah yang dapat maju dalam kontestasi pemilihan kepala daerah dengan syarat sebagaimana terdapat pada pasal 7 ayat (2) huruf g, yaitu tidak pernah sebagai terpidana berdasarkan putusan pengadilan yang telah memperoleh kekuatan hukum tetap atau bagi mantan terpidana telah secara terbuka dan jujur mengemukakan kepada publik bahwa yang bersangkutan mantan terpidana. Lebih lanjut pada bagian penjelasan menentukan bahwa ketentuan permohonan maaf diatas tidak berlaku sepanjang yang dilakukan adalah tindak pidana perdaran narkotika dan kejahatan seksual.

Pasal 7 ayat (2) huruf g tersebut telah dilakukan uji materi ke Mahkamah Konstitusi (MK) dan telah diputus melalui Putusan Nomor 71/PUU-XIV/2016. Melalui putusan tersebut MK telah menyatakan pasal 7 ayat (2) huruf g tersebut inkonstitutional, sepanjang tidak dimaknai terpidana dengan putusan minimal lima tahun. Artinya bagi putusaan pidana di bawah lima tahun tetap dapat mengajukan diri dalam ajang kontestasi pemilihan kepala daerah. Hal tersebut dipandang oleh penulis sebagai ironi pemberantasan tindak pidana korupsi, karena sebagaimana 
data Indonesia Coruption Watch (ICW) yang menunjukkan vonis perkara korupsi dari tahun 2014 hingga tahun 2018 sebanyak 84 kepala daerah yang disidangkan di tingkat pertama, 41 diantaranya dihukum ringan, yakni dihukum 1 sampai 4 tahun (Suparman, 2018). Pasca putusan MK Nomor 71/ PUU-XIV/2016 serta dengan melihat trend putusan perkara korupsi tersebut, maka sedikit banyak akan berdampak kepada upaya mencari pemimpin yang memiliki kredibilitas dan integritas melalui Pemilihan Umum (Pemilu), karena mantan terpidana korupsi dapat mencalonkan diri dalam kontestasi pemilihan kepala daerah.

Putusan MK Nomor 71/PUU-XIV/2016 tersebut memberikan celah bagi mantan terpidana korupsi untuk dapat dipilih dalam Pemilihan Kepala Daerah (Pilkada), dan tidak menutup kemungkinan pula terpilih untuk menduduki posisi kepala daerah. Padahal pembatasan seorang mencalonkan kembali di dalam pelaksanaan kontestasi pemilihan kepala daerah yang terdapat di dalam Undang-undang No. 10 Tahun 2016 sebelum putusan MK Nomor 71/PUU-XIV/2016, merupakan arah pencgahan yang secara esensi adalah pembatasan hak politik seseorang. Pencabutan yang demikian juga terdapat di dalam jenis sanksi pidana tambahan. Pembatasan hak politik dalam Undang-undang No. 10 Tahun 2016, memiliki kesamaan dengan pencabutan hak politik sebagai sanksi pidana, yaitu dalam hal tujuan pencegahan bagi orang yang dibatasi hak politiknya, agar tidak melakukan kembali perbuatan jahatanya. Pencegahan sebagaimana dimaksud juga sebagai pengejawantahan pembaruan hukum pidana yang berlandaskan kepada Pancasila sebagai suatu nilai induk dari hukum yang secara filososfis mengandung keadilan. Argumentasi penulis didasarkan kepada pendapat dari Barda Nawawi Arief mengenai hakikat pembaharuan hukum pidana menanggulangi konflik dalam rangka menyelesaikan konflik (Fatoni, 2015). Hal tersebut memiliki makna bahwa penanggulangan tidak serta merta menghukum (represif) namun orientasinya adalah selesainya konflik, yang bisa dilakukan dengan jalan pencegahan.
Kenyataan bahwa banyak putusan pengadilan yang memberikan vonis terhadap pelaku tindak pidana korupsi di bawah 5 tahun, yang memudahkan seorang mantan narapidana korupsi untuk melenggang mencalonkan kembali dalam kontestasi pemilihan kepala daerah memunculkan kekhawatiran tersendiri mengingat posisi kepala daerah berhubungan erat dengan kekuasaan dan kewenangan publik, yang dapat berkorelasi dengan penyalahgunaan kewenangan (abuse of power) untuk keuntungan pribadi yang merugikan negara. Padahal pemilihan umum merupakan ajang demokrasi yang tujuanya mencari orang-orang yang berintegritas dan bisa mengemban amanah rakyat untuk menduduki jabatan pimpinan daerah (Hanafi, 2016). Berdasarkan permasalahan yang telah penulis jabarkan di atas dalam tulisan ini penulis akan meninjau Putusan MK Nomor 71/PUU-XIV/2016 perihal putusan yang membatalkan ketentuan larangan bagi mantan narapidana mencalonkan sebagai kepala daerah. Berkaitan dengan putusan tersebut penulis akan melakukan kontruksi terhadap sanksi pencabutan hak politik sebagai upaya pencegahan korupsi pasca keluarnya Putusan MK Nomor 71/PUU-XIV/2016.

\section{Metode Penelitian}

Penelitian ini menggunakan metode penelitian hukum normatif yaitu melakukan kajian terhadap norma dalam bentuk peraturan perundang-undangan. Penelitian ini akan menggunakan pendekatan peraturan perundang-undangan (statute approach) Pendekatan konsep (conseptual approach) yaitu menggunakan konsep-konsep hukum pidana yang relevan dengan penelitian ini. Penulis akan menggunakan teknik analisa menggunakan teknik interpretasi secara gramatikal dan sistematis terhadap bahan hukum yang digunakan.

\section{Pembahasan}

\section{Tinjauan Yuridis Putusan MK Nomor 71/ PUU-XIV/2016}

Undang-undang No. 10 Tahun 2016 sebagai regulasi dalam pemilihan kepala daerah bertujuan mengejawantahkan prinsip 
demokrasi untuk mencari pemimpin yang berkualitas dalam mengemban amanah rakyat. Perubahan Pasal 7 ayat (2) huruf g, mensyaratkan bahwa calon gubernur dan calon wakil gubernur, calon bupati dan caIon wakil bupati, serta calon walikota dan calon wakil walikota, adalah sosok yang tidak pernah sebagai terpidana berdasarkan putusan pengadilan yang telah memperoleh kekuatan hukum tetap. Hal tersebut dapat ditafsirkan bahwa semua mantan narapidana tidak boleh mencalonkan diri, tidak terkecuali mantan narapidana korupsi. Tetapi syarat tersebut dikecualikan, jika calon yang merupakan mantan terpidana ini telah secara terbuka dan jujur mengemukakan kepada publik bahwa yang bersangkutan mantan terpidana. Pada bagian penjelasan Pasal 7 ayat (2) huruf $\mathrm{g}$, menjelaskan bahwa pengecualian tersebut tidak berlaku terhadap mantan narapidana kejahatan seksual dan narkotika.

Mengenai Pasal 7 ayat (2) huruf g, Putusan MK nomor 71/PUU-XIV/2016 memberikan ketentuan, yang intinya bahwa "tidak pernah dipidana" sebagai syarat calon gubernur dan calon wakil gubernur, calon bupati dan calon wakil bupati, serta calon walikota dan calon wakil walikota, hanya berlaku bagi terpidana yang mendapatkan putusan di atas lima tahun penjara. Sehingga bagi mantan terpidana apapun yang pernah dihukum di bawah lima tahun penjara, dapat mencalonkan diri. Kecuali, ia sedang menjalani sanksi pencabutan hak politik.

Disinilah tampak implikasi negatif terbitnya putusan MK Nomor 71/PUUXIV/2016 terhadap pembatasan seseorang mencalonkan diri pada kontestasi pemilihan kepala daerah. Seorang mantan narapidana (apapun tindak pidananya, kecuali kejahatan seksual dan narkotika), selama ia hanya diputus di bawah lima tahun, maka ia dapat mencalonkan diri. Ketentuan tersebut berlaku juga bagi mantan narapidana tindak pidana korupsi yang telah menjalani hukuman penjara di bawah lima tahun, di mana ia dapat mencalonkan diri selama ia tidak sedang menjalani sanksi pencabutan hak politik. Menjadi persoalan, bahwa sanksi dalam tindak pidana korupsi, sebagian besar diputus di bawah lima tahun dari tahun 2014 hingga tahun 2018 sebanyak 84 kepala daerah yang disidangkan di tingkat pertama, menunjukkan 41 diantaranya dihukum ringan, yakni dihukum 1 sampai 4 tahun (Suparman, 2018).

Memperhatikan implikasi negatif dari putusan MK nomor 71/PUU-XIV/2016 tersebut maka penulis memandang hal itu merupakan sebuah kemunduran dalam pencegahan korupsi, serta tidak mencerminkan keadilan. Adapun alasan penulis berpendapat demikian adalah bahwa korupsi merupakan tindak pidana yang menciderai amanat rakyat serta bertentangan dengan nilai-nilai kejujuran (Mastalia, 2017). Korupsi sejatinya merupakan kejahatan yang merugikan rakyat dan mengingkari amanah yang diberi rakyat dalam bentuk kekuasaan dalam menentukan kebijakan. Sehingga mantan terpidana koruptor pada hakikatnya merupakan orang yang telah bermasalah dengan amanah yang diemban pada jabatan sebelumnya. Bisa diibaratkan seseorang yang pernah melakukan perbuatan tidak jujur atas amanah yang diterimanya, akan cenderung melakukan hal yang serupa karena kekuasaan yang dimilikinya. Berhubungan dengan kekuasaan Artidjo Alkostar menyebutkan sifat dari watak kekuasaan pada dasarnya berambisi untuk memperbesar pengaruh, memperluas jangkauan (Alkostar, 2008).

Fakta rendahnya putusan hakim terhadap perkara tindak pidana korupsi juga bisa menjadi faktor yang mempengaruhi pelaku korupsi mengulangi kembali perbuatannya. Putusan MK nomor 71/PUU-XIV/2016 yang memberikan limitasi mantan terpidana korupsi dapat mencalonkan pada kontestasi pemilihan kepala daerah merupakan celah dan faktor penyebab korupsi dari sisi hukum. Faktor hukum yang menjadi penyebab terjadinya korupsi dibagi menjadi dua yakni aspek regulasi dan aspek penegakan hukum (Tim Penulis Buku Pendidikan Anti Korupsi, 2011). Putusan MK yang setara dengan undang-undang karena sifatnya negative legislator yang memiliki makna Mahkamah Konsitusi bukan pembentuk undang-undang seperti halnya lembaga legislative (Pratiwi, 2018). 
Jika dikaitkan dengan keberadaan Putusan MK Nomor 71/PUU-XIV/2016 menjadi kelemahan pemberantasan korupsi dan menjadi faktor hukum timbulnya korupsi. Kelemahan pemberantasan korupsi dari faktor hukum ialah penegakan yang tidak memutus berat pelaku, tidak memberikan efek jera dan memungkinkan pelaku melakukannya kembali dikemudian hari. Tentunya putusan MK ditunjang dengan putusan perkara korupsi yang sejauh ini relatif rendah, akan memberi kontribusi lemahnya upaya penanggulangan korupsi.

Kerugian negara akibat korupsi menurut Lilik Mulyadi, secara sederhana, adalah berupa ruginya atau berkurangnya keuangan negara (Damanik, 2016), yang itu meliputi kerugian secara luas maupun secara sempit. Kerugian negara secara sempit mencakup kerugian keuangan negara yang berdampak terhadap kerugian pada sektor lain, sedangkan untuk cakupan yang luas karena secara fungsi keuangan negara penggunaannya untuk dipergunakan sepenuhnya bagi kepentingan rakyat. Mempertimbangkan kerugian yang ditimbulkan, apabila terdapat kebijakan dalam bentuk regulasi yang memperlemah pemberantasan korupsi maka itu merupakan bentuk pengingkaran terhadap keadilan yang dicita-citakan oleh Pancasila.

Perlu diketahui bahwa pertimbangan MK pada Putusan Nomor 71/PUU-XIV/2016 adalah sebagai penghormatan hak sipil dan hak politik. Padahal apabila didasarkan kepada alasan tersebut masih bisa diperdebatkan, di mana hak untuk terlibat dalam pemerintahan merupakan hak yang sifatnya dapat dibatasi dalam situasi tertentu (kondisi darurat) yang mengancam hajat orang banyak (Matompo, 2014). Apalagi pembatasan keterlibatan warga negara tersebut tidak didukung oleh trend putusan perkara korupsi yang cenderung masih relatif rendah (yaitu di bawah lima tahun) sebagaimana yang telah penulis uraikan di atas. Penulis memandang bahwa situasi kejahatan korupsi yang terjadi di Indonesia masih dalam kondisi darurat.

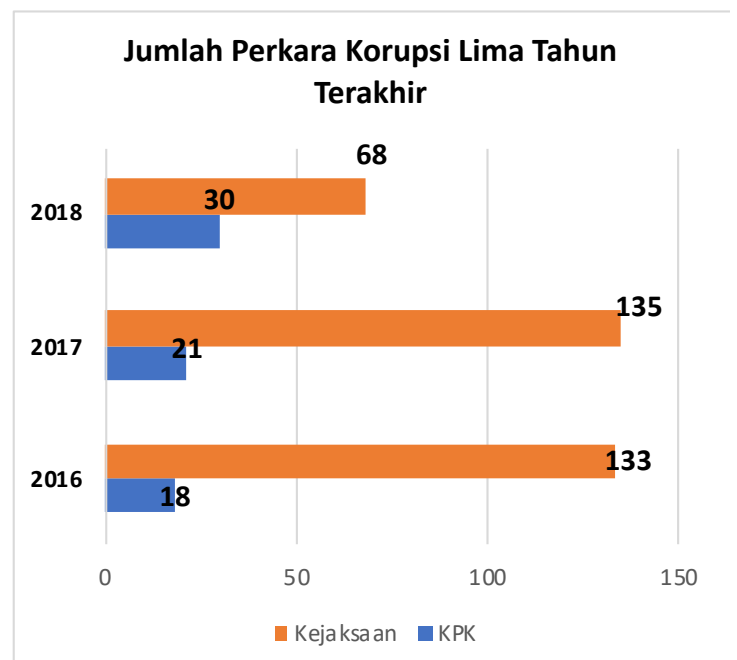

Gambar 1. Jumlah Perkara Korupsi Lima Tahun Terakhir

Sumber : Rilis Indonesia Corruption Watch (Putri, 2018)

Memperhatikan grafik di atas, maka semakin kuat argumentasi penulis meletakkan korupsi saat ini di Indonesia dalam situasi darurat. Sehingga tidak salah jika korupsi dikategorikan sebagai serious crime bahkan ada yang melebeli korupsi sebagai extra ordinary crime.

Kiranya benar jika mengatakan putusan MK nomor 71/PUU-XIV/2016 tidak memiliki alasan pembenar dan terindikasi tidak sejalan dengan upaya pemberantasan korupsi di Indonesia. Kekhawatiran tersebut semakin diperkuat dengan kasus kongkrit yang melibatkan Bupati Kabupaten Kudus Muhammad Tamzil yang mana pada periode pertama kepemimpinannya (2003-2008) divonis selama 22 Bulan karena melakukan tindak pidana korupsi. Kemudian pada tahun 2008 terpilih kembali menjadi Bupati Kudus. Pada periode kedua kepemimpinannya ini pada tahun 2019 terjerat kasus korupsi suap jual beli jabatan (Tempo.co, 2019). Hal tersebut menandakan bahwa kepala daerah yang telah menjalani masa pidana tidak mampu mencegah melakukan korupsi kembali. Tentunya hal tersebut cukup menjadi landasan jika putusan MK Nomor 71/PUU-XIV/2016 tidak selaras dengan upaya pemberantasan tindak pidana korupsi. 


\section{Sinergitas Sanksi Pencabutan Hak Politik Bagi Terpidana Korupsi dan Pembatasan Pencalonan Kepala Daerah di Indonesia dalam Rangka Pencegahan Korupsi}

Kedudukan Sanksi Pencabutan Hak Politik Bagi Terpidana Korupsi Dalam Hukum Positif Indonesia Saat ini dan RKUHP Nasional

Jenis-jenis sanksi pidana tidak akan terlepas dari tujuan pidana, di mana setiap bentuk sanksi pidana memiliki tujuannya sendiri-sendiri. Selain itu sanksi pidana memiliki karakteristik yang membedakan dengan sanksi hukum lainnya. H.L.A Hart mengatakan mengenai syarat sanksi pidana yaitu adanya penderitaan dan kosekuensi lain yang tidak menyenangkan (Bertin, 2016). Untuk sanksi pidana berupa "pencabutan hak tertentu", sanksi ini ditujukan untuk menderitakan seseorang dalam wujud tidak diperbolehkannya seseorang untu mendaptakan hak-hak tertentu, salah satunya adalah hak politk berupa hak untuk mencalonkan diri dan dipilih dalam suatu perhelatan pemilihan umum.

Pada dasarnya, sanksi pencabutan hak politik ini mengacu pada ketentuan Kitab Undang-undang Hukum Pidana (KUHP) Pasal 35, di mana sanksi tersebut diletakkan sebagai jenis sanksi pidana tambahan mengenai saknsi pencabutan hak-hak tertentu. Hak tertentu tersebut meliputi: pertama, hak memegang jabatan tertentu, kedua, hak memasuki angkatan bersenjata, ketiga, hak memilih dan dipilih dalam pemilihan yang diadakan berdasarkan aturan perundangundangan, keempat, hak menjadi penasihat hukum, kelima, hak menjalankan kekuasaan bapak, dan keenam, hak menjalankan mata pencaharian tertentu.

Lebih lanjut mengenai sanksi pencabutan hak politik ini diatur di Undang-undang Nomor 31 Tahun 1999 tentang Pemberantasn Tindak Pidana Korupsi jo. Undang-Undang Nomor 20 Tahun 2001 tentang Perubahan Undang-undang Nomor 31 Tahun 1999 tentang Pemberantasn Tindak Pidana Korupsi, yaitu di Pasal 18 mengenai pidana tambahan. Tujuan pidana pencabutan hak tertentu, yang didalamnya hak untuk memilih dan dipilih, merupakan bentuk proteksi negara ter- hadap bangsa demi tercipta masyarakat yang good and clean governance, yang terbebas dari korupsi, kolusi dan nepotisme.

Dalam Rancangan KUHP Nasional draft tahun 2019 juga tetap mengadopsi jenis sanksi pencabutan hak tertentu, yaitu di Pasal 86. Kedudukannya tetap sebagai jenis sanksi pidana tambahan, dan mengenai sanksi pencabutan hak politik juga masuk dalam kategori hak yang dapat dicabut, di mana rumusan tersebut tidak berbeda jauh dengan ketentuan yang ada di KUHP saat ini. Pengaturan sanksi pencabutan hak politik di RKUHP Nasional menggambarkan, bahwa sanksi tersebut dinilai masih selaras dengan tujuan pidana dan pemidanaan di Indonesia di masa mendatang. Mengenai tujuan pidana dan pemidanaan sendiri, akan penulis perdalam pada pembahasan berikutnya. Selain mendasarkan pada ketentuan di KUHP maupun di undang-undang tipikor, beberapa putusan hakim terkait perkara korupsi juga telah menjatuhkan sanksi pencabutan hak politik, dan sebatas penelusuran penulis, pertama kali dijatuhkan pada kasus korupsi yang melibatkan LHI dalam perkara ekspor-impor sapi, sekitar tahun 2014 melalui putusan Mahkamah Agung Nomor 1195 K/Pid.Sus/2014 dengan ketua majelis Hakim Artidjo Alkostar.

Pembatasan Hak Politik Mantan Terpidana Korupsi Sebagai Pengejawantahan Keadilan Pancasila

Sebagaimana yang telah penulis jelaskan di atas, bahwa keluarnya putusan MK Nomor 71/PUU-XIV/2016 memunculkan implikasi yang kurang positif terhadap upaya pencegahan tindak pidana korupsi, khususnya dalam rangka pemilihan umum untuk mewujudkan pemerintahan yang baik dan bersih. Putusan MK tersebut memiliki kecenderungan membiarkan mantan terpidana korupsi menduduki jabatan publik, karena memberikan persyaratan limitasi pidana penjara yang tinggi, sedangkan trend penjatuhan sanksi penjara kepada terdakwa korupsi di Indonesia menunjukkan bahwa sebagian besar masih diputus rendah, yakni di bawah lima tahun. Pada situasi ini peranan dari sanksi pencabutan hak politik dirasa penting, guna membatasai hak para mantan narapi- 
dana korupsi yang diputus pidana penjara di bawah lima tahun. Tetapi yang menjadi persoalan adalah, penjatuhan sanksi pencabutan hak politik menunjukkan trend yang kurang populer untuk dijatuhkan bersamaan dengan sanksi pidana pokok, bahkan sebagian besar sanksi ini dijatuhkan justru kepada terpidana korupsi yang diberikan sanksi penjara di atas lima tahun. Contohnya pada perkara korupsi Luthfi Hasan Ishaq, Anas Urbaningrum, dll.

Undang-undang Nomor 12 Tahun 1995 tentang Pemasyarakatan pada bagian Penjelasan Umum alinea pertama telah menentukan, bahwa negara Indonesia yang berdasarkan Pancasila, pemikiran-pemikiran baru mengenai fungsi pemidanaan yang tidak lagi sekedar penjeraan tetapi juga merupakan suatu usaha rehabilitasi dan reintegrasi sosial pelaku kejahatan. Jika dikorelasikan dengan ketentuan di RKUHP Nasional draft tahun 2019 merumuskan mengenai tujuan pemidanaan di Pasal 51 huruf a, adalah untuk mencegah dilakukannya tindak pidana dengan menegakkan norma hukum demi pengayoman masyarakat, maka didapat sebuah benang merah dalam melihat mengenai tujuan pemidanaan, yaitu:

1) Pemidanaan tidak ditujukan hanya sekedar untuk menjerakan pelaku kejahatan, tetapi diprioritaskan untuk merehabilitasi dan meresosialisasinya. Jadi dalam hal ini mengacu pada teori relatif, khususnya teori pencegahan khusus (Speciale detterence/Speciale preventie), tetapi tidak dengan menyingkirkan pelaku dari masyarakat.

2) Pencegahan sebagai tujuan pemidanaan yang dicita-citakan di RKUHP, harus berkorelasi dengan penegakan norma hukum dan juga berkorelasi dengan tujuan perlindungan/pengayoman masyarakat. perlindungan masyarakat sebagai tujuan pemidanaan didasarkan pada teori "perlindungan masyarakat" (The Theory of Social Defence) yang dikemukakan oleh John Andenaes (Soponyono, 2012).

Sehingga pada hakikatnya, penjatuhan sanksi pidana pencabutan hak politik sebagai bentuk pidana tambahan bagi terpidana ko- rupsi, merupakan metode pemidanaan yang lebih humanis dibandingkan jika hanya sekedar memenjara yang bersangkutan. Melalui sanksi tersebut, seorang terpidana korupsi dapat lebih cepat menjalani proses resosialisasi di tengah-tengah kehidupan bermasyarakat, ketimbang berlama-lama menjalani kehidupan di lembaga pemasayarakatan (penjara). Jika memandang kejahatan (termasuk korupsi) sebagai suatu gangguan terhadap keseimbangan (evenwichtstoring), keselarasan, dan keserasian, dalam kehidupan masyarakat yang mengakibatkan kerusakan individual maupun masyarakat, maka upaya mengembalikan pelaku ke tengah masyarakat merupakan upaya perbaikan akibatakibat dari kejahatan yang dilakukan pelaku (Muladi, 1985).

Hal tersebut juga searah dengan usaha pencapaian keadilan restoratif, di mana jika dipandang sebagai konsep nilai, maka keadilan restoratif ini mengandung nilai-nilai yang berbeda dari pada keadilan biasa. Yaitu keadilan restoratif ini lebih menitikberatkan pada pemulihan, bukan pada penghukuman. Tetapi usaha pemulihan dan meresosialisasi pelaku kejahatan, khususnya pelaku korupsi, tidak serta merta diberikan tanpa seiring sejalan dengan upaya perlindungan/pengayoman masyarakat. Terlebih lagi korupsi merupakan kejahatan yang menjadikan rakyat banyak/ masyarakat sebagai korban, sehingga upaya pemulihan dalam hal ini haruslah seimbang, antara pelaku dengan korban. Korupsi pada hakikatnya merupakan kejahatan yang menyerang perasaan kepercayaan rakyat terhadap amanah yang diembankan kepada pelaku. Sehingga kepercayaan itu pula lah yang harus dipulihkan. Maka dari itu, tolak ukur seseorang mantan terpidana korupsi dapat mencalonkan diri sebagai pejabat publik, tidak hanya pada pengakuan bersalah atau permintaan maaf dari pelaku saja, tetapi yang lebih esensi adalah pulihnya rasa keperecayaan yang dimiliki oleh rakyat/masyarakat kepada mantan pelaku korupsi.

Selain itu, adanya pengaturan mengenai sanksi pencabutan hak politik di dalam RKUHP Nasional, itu menandakan bahwa jenis sanksi tersebut dipandang sejalan den- 
gan tujuan pemidanaan sebagaimana di Pasal 51 huruf a, dan relevan untuk diterapkan sebagai upaya pencegahan tindak pidana korupsi sekaligus upaya perlindungan masyarakat saat ini di Indonesia, maupun di masa mendatang. Jika dipandang dari perspektif teori pencegahan umum, penulis mengutip pendapat Ted Honderich yang menjelaskan bahwa hukum pidana dinilai efektif apabila pidana dapat mencegah pelaku melakukan kembali perbuatan jahat dan masyarakat umum tidak melakukan kejahatan (Fatoni, 2015).

Pancasila sebagai falsafah hidup bangsa Indonesia mengamanahkan mengenai persoalan keadilan, pemerataan, dan kemanusiaan. Sehingga penegakan hukum pidana nasional sudah saatnya untuk lebih memperhatikan hak-hak korban kejahatan/tindak pidana, sebagai wujud dari perlindungan masyarakat. Sebagaimana yang disampaikan oleh Muladi, bahwa dalam penanganan perkara pidana sudah saatnya memberikan perhatian khusus terhadap kepentingan korban (Muladi, 1985). Sebagai subjek hukum, korban memiliki kedudukan yang sederajat di depan hukum (equality before the law), sehingga perhatian kepada korban hendaknya dilakukan atas dasar belas kasihan dan hormat atas martabat korban sebagai seorang manusia (compassion and respect for their dignity) (Muladi, 2005). Jika menganatomi persoalan kejahatan korupsi, maka pihak yang paling dirugikan adalah rakyat/masyarakat, di mana korupsi tidak hanya mencuri uang rakyat tetapi juga menciderai kepercayaan atas amanah rakyat yang telah diberikan. Maka dari itu, ide keseimbangan dalam filosofi Pancasila, jika dikaitkan dengan pidana dan pemidanaan, maka harus ada keseimbangan dalam hal tujuan pemidanaan itu sendiri, baik itu yang didapat oleh pelaku maupun dengan yang didapat oleh rakyat sebagai korban. Tujuan pemidanaan yang dimaksud penulis meliputi tujuan resosialisasi dan rehabilitasi bagi pelaku, serta tujuan perlindungan bagi masyarakat.

Nampak ide keseimbangan ini merupakan hal krusial di dalam berhukum dengan bingkai Pancasila, sehingga pembaha- ruan hukum pidana Indonesia menjunjung tinggi keseimbangan-keseimbangan yakni keseimbangan antara bagian-bagian dalam masyarakat, antara tujuan pribadi dan tujuan bersama. Pada posisi ini maka peran penting hukum, yaitu untuk meminimalisir dan mengantisipasi adanya benturan antara dua kepentingan tersebut (Nasution, 2014). Ada tiga prinsip keadilan, salah satunya adalah prinsip persamaan yang adil atas kesempatan. Jika penulis kaitkan pula dengan pendapat Yudi Latif mengenai komitmen keadilan sosial menurut alam pemikiran Pancasila yang berdimensi luas, maka tolak ukur keadilan terletak pada peran negara (Fajrin \& Triwijaya, 2019). Menurut beliau, prinsip keadilan sosial dalam kerangka Pancasila, negara haruslah berperan dalam kerangka: mewujudkan relasi yang adil di semua tingkat sistem kemasyarakatan, dan pengembangan struktur yang menyediakan kesetaraan kesempatan. Memperhatikan dua pendapat tersebut mengenai keadilan, serta mengkorelasikannya dengan persoalan pembatasan hak politk (baik itu melalui sarana sanksi pencabutan hak politk maupun melalui sarana syarat calon pejabat publik yang tidak memiliki riwayat sebagai narapidana), maka keadilan sosial dalam hal ini dicerminkan dalam prinsip persamaan kesempatan. Pembatasan hak politik melalui dua mekanisme tersebut, memberikan peluang/kesempatan seluas-luasnya bagi pihak-pihak atau pribadi-pribadi yang masih bersih dan belum pernah berurusan dengan persoalan hukum, untuk dapat mencalonkan diri sebagai pejabat publik. Selain itu, mekanisme pembatasan hak politk melalui dua mekanisme tersebut, memberikan peluang/ kesempatan bagi rakyat/masyarakat untuk memilih orang-orang atau pribadi-pribadi yang masih bersih dan belum pernah berurusan dengan hukum untuk menjadi pemimpin mereka (masyarakat/rakyat). Begitu juga sebaliknya, jika pembatasan hak politik melalui dua mekanisme ini dikesampingkan oleh negara, maka hal tersebut memposisikan negara sebagai pihak yang membatasi hak rakyat/msayarakat untuk mendapatkan pilihan/ calon yang bersih.

Pada prinsipnya perlindungan masyarakat melalui sarana pidana dan pemidanaan 
merupakan salah satu tujuan untuk mencapai cita-cita keadilan sosial sebagaimana yang diamanahkan oleh Pancasila. Sehingga tujuan pencegahan dan perlindungan masyarakat selaras dengan cita-cita keadilan sosial. Menurut Mahfud MD keadilan secara esensi adalah adanya pendistribusian sumberdaya (penulis memaknai ini sebagai pendistribusian kesejahteraan) bagi masyarakat bawah agar jarak antara kaya dan miskin tidak terlalu jauh. Makna keadilan menurut Pancasila dengan apa yang dikemukakan oleh pemikian filsuf Barat, secara esensial adalah sama. Sebagaimana dikatakan Ulpianus, bahwa adil adalah kemauan yang sifatnya tetap dan terus menerus sebagai ukuran memberikan kepada setiap orang sebagaimana mestinya (Fajrin \& Triwijaya, 2019). Menurut penulis inti dari keadilan Pancasila adalah adanya kesejahteraan. Terlihat adanya hubungan integral antara kebijakan kriminal dan kebijakan sosial karena pada hakikatnya tujuan yang hendak dicapai adalah sosial welfare.

Pembatasan hak politik bagi mantan narapidana korupsi, dipandang oleh penulis sebagai suatu yang mendesak/urgent untuk mensinergikan antara mekanisme pencabutan hak politik dengan mekanisme pembatasan syarat calon pejabat publik. Hal tersebut didasarkan kepada pendapat Romli Atmasasmita, di mana korupsi sudah merupakan ancaman yang bersifat serius terhadap stabilitas dan keamanan masyarakat nasional dan internasional (Bhakti \& Djauhari, 2017). Pendapat tersebut dapat diartikan bahwa korupsi merupakan perbuatan yang membawa dampak kepada ketahanan sosial, ketahanan ekonomi, dan ketahanan budaya. Selain itu bahaya korupsi juga berpengaruh terhadap upaya penyejahteraan khususnya berhubungan dengan pelayanan publik sehingga korupsi merupakan penyakit sosial yang bersifat universal dan telah terjadi semenjak awal perjalanan sejarah kehidupan manusia. Sehingga apabila dihubungkan dengan tujuan keadilan yang terkandung di dalam Pancasila, maka korupsi telah mengingkari nilainilai keadilan Pancasila berupa kesejahteraan rakyat.

Maka dari itu, antara sanksi pidana "pencabutan hak politik" bagi terpidana korupsi dan ketentuan mengenai batasan syarat calon pemangku jabatan, perlu untuk disinergikan sebagai upaya mewujudkan cita-cita pemerintah yang baik dan bersih, yang mampu memberikan jaminan perlindungan masyarakat sebagai perwujudan nilai keadilan sosial. Adapun upaya sinergitas dua instrumen tersebut adalah sebagai berikut:

1) Penjatuhan sanksi pencabutan hak politik harus lebih diprioritaskan untuk dijatuhkan oleh hakim dalam putusannya kepada terpidana korupsi yang dijatuhi sanksi penjara di bawah lima tahun. Sedangkan bagi terpidana korupsi (atau kejahatan lainnya) yang dijatuhi pidana penjara di atas lima tahun, telah tunduk dan patuh pada ketentuan Pasal 7 ayat (2) huruf g, jo. Putusan MK Nomor 71/PUU-XIV/2016. Sehingga pelaku korupsi yang dijatuhi hukuman di atas lima tahun, tidak perlu terhadapnya diberikan sanksi pencabutan hak politik.

2) Seiring terbitnya putusan MK Nomor 71/PUU-XIV/2016 maka perlu adanya upaya rekontruksi ketentuan yang tertuang di Undang-undang No. 10 Tahun 2016 perubahan Pasal 7 ayat (2) huruf g serta pada bagian Penjelasannya, sehingga posisi mantan terpidana korupsi setingkat dengan mantan pelaku kejahatan seksual dan narkotika. Ide tersebut didasarkan pada argumentasi sebagai berikut:

a) Kejahatan korupsi dapat digolongkan sebagai organized crime sebagaimana kejahatan narkotika;

b) Korban dan kerugian kejahatan korupsi bersifat massif, sama halnya dengan kejahatan narkotika;

c) Kejahatan korupsi tidak hanya merugikan secara keuangan/ ekonomi saja, tapi secara esensi juga menyerang rasa percaya (kepercayaan) yang diberikan oleh rakyat/masyarakat kepada pelaku. Hal tersebut tidak berbeda jauh dengan kejahatan seksual, yang menyerang rasa kesusilaan dan 
kemanusiaan masyarakat.

Dengan demikian pembatasan hak politik mantan terpidana korupsi merupakan bentuk pencegahan korupsi, Pencegahan sendiri merupakan pengejawantahan perlindungan masyarakat sebagai korban tindak pidana. Pembatasan hak politik ini dapat dikatakan diperbolehkan karena hak politik merupakan bagian dari hak asasi yang sifatnya derogable, yakni dapat dikesampingkan sepanjang sebanding dengan ancaman yang mengganggu keamanan nasional atau situasi darurat yang dihadapi dan tidak bersifat diskriminatif terhadap ras dan etnis (Matompo, 2014).

\section{Kesimpulan}

Putusan MK Nomor 71/PUU-XIV/2016 menurut penulis telah menciptakan keadaan baru berupa kemunduran terhadap pencegahan korupsi. Argumentasi penulis tersebut didasarkan karena mantan terpidana korupsi yang dipidana penjara di bawah lima tahun mendapatkan kesempatan untuk dapat mencalonkan diri sebagai calon kepala daerah termasuk mantan terpidana korupsi. Padahal sebagian besar perkara korupsi di Indonesia, hukuman yang dijatuhkan adalah penjara di bawah lima tahun. Putusaan MK Nomor 71/ PUU-XIV/2016 tidak mencerminkan keadilan apabila memperhatikan dampak korupsi, salah satunya yaitu menciderai amanat rakyat karena tidak menutup kemungkinan korupsi dapat kembali dilakukan oleh mantan terpidana korupsi ketika kembali menjabat melalui penggunaan hak politiknya.

Terkait dengan kelemahan pencegahan korupsi yang disebabkan oleh Putusaan MK Nomor 71/PUU-XIV/2016 terdapat dua mekanisme pencegahan korupsi yang dilakukan oleh pejabat publik, khususnya kepala daerah. Yaitu, pertama, mekanisme sanksi pencabutan hak politik bagi terpidana korupsi, dan kedua, mekanisme syarat menjadi calon kepala daerah yang tidak pernah berstatus sebagai terpidana. Namun pasca putusan MK Nomor 71/PUU-XIV/2016 memberikan celah bagi mantan narapidana korupsi untuk mencalonkan diri. Sehingga pasca putusan MK ini, perlu ada upaya sinergitas antara dua mekanisme pencegahan korupsi tersebut. Serta perlu ada upaya merekonstruksi rumusan Pasal 7 ayat (2) huruf g, yang memasukkan putusan MK Nomor 71/PUU-XIV/2016 tersebut dalam rumusan, serta mendudukkan korupsi setingkat dengan kejahatan seksual dan narkotika sebagai syarat mantan narapaidana yang tidak dapat mencalonkan diri.

\section{Daftar Pustaka}

Alkostar, A. (2008). Mengkritisi Fenomena Korupsi di Parlemen. Jurnal Hukum Ius Quia lustum, 15(1), 1-13. https://doi.org/10.20885/iustum.vol15. iss1.art2

Bertin. (2016). Analisis Disparitas Pidana Dalam Kasus Pemerkosaan. Jurnal Katalogis, 4(11), 67-78.

Bhakti, S. A. E., \& Djauhari. (2017). Upaya Pencegahan Tindak Pidana Korupsi Melalui Peran Serta Masyarakat. Jurnal Hukum Khaira Ummah, 12(2), 385-399. https://doi.org/10.24815/kanun. v16i3.6037

Damanik, K. G. (2016). Antara Uang Pengganti Dan Kerugian Negara Dalam Tindak Pidana Korupsi. Masalah-Masalah Hukum, 45(1), 1. https://doi. org/10.14710/mmh.45.1.2016.1-10

Fadhil, H. (2019). 5 Tahun Terakhir, Total Rp 1,6 T Aset Diselamatkan KPK dari Korupsi. Detiknews.Com. https://news.detik.com/ berita/d-4454657/5-tahun-terakhir-total-rp16-t-aset-diselamatkan-kpk-dari-korupsi

Fajrin, Y. A., \& Triwiwijaya, A. F. (2019). Pencegahan Korupsi Pasca Putusan MK Nomor 71 / PUU / XIV / 2016 Melalui Pendekatan Kebijakan Corruption Prevention After Constitutional Court Decision Number 71 / PUU / XIV / 2016 Through Policy Approach. HUMANI (Hukum Dan Masyarakat Madani), 9(1), 30-56.

Fatoni, S. (2015). Pembaruan Hukum Pidana Melalui Aktualisasi Nilai-Nilai Pancasila Berorientasikan Pendekatan Religius. Ahkam: Jurnal Hukum Islam, 3(1), 43-66. https://doi.org/10.21274/ahkam.2015.3.1.41-64

Hanafi, R. I. (2016). Pemilihan Langsung Kepala Daerah di Indonesia: Beberapa Catatan Kritis Untuk Partai Politik. Jurnal Penelitian Politik, 11(2), 16. https://doi.org/10.14203/jpp.v11i2.197

Jayani, D. H. (2019). Sejak 2004 hingga 2019, Terdapat 124 Kepala Daerah Terjerat Korupsi. Databoks. Katadata.Co.Id. https://databoks.katadata. co.id/datapublish/2019/07/13/sejak-2004-hingga-2019-terdapat-124-kepala-daerah-terjeratkorupsi

Mashabi, S. (2020). Indeks Persepsi Korupsi Indonesia pada 2019 Naik Jadi 40. Kompas.Com. https://nasional.kompas.com/ $\mathrm{read} / 2020 / 01 / 23 / 16565951 /$ indeks-persepsikorupsi-indonesia-pada-2019-naik-jadi-40

Mastalia, A. (2017). Kedudukan Pidana Mati Sebagai Dalam Pidana Korupsi. Syiar Hukum, 15(1), 1689-1699. https://doi.org/10.1017/ CBO9781107415324.004 
Yaris A. Fajrin \& Ach. F. Triwijaya, Pencegahan Korupsi Melalui Pencabutan Hak Politik Sebuah Telaah ...

Matompo, O. S. (2014). Pembatasan Terhadap Hak Asasi Manusia Dalam Prespektif Keadaan Darurat. Media Hukum, 21(1), 57-72. https://media. neliti.com/media/publications/113633-IDpembatasan-terhadap-hak-asasi-manusia-da. pdf

Muladi. (1985). Lembaga Pidana Bersyarat. Alumni.

Muladi. (2005). Hak Asasi Manusia. Refika Aditama.

Nasution, B. J. (2014). Kajian Filosofis Tentang Konsep Keadilan Dari Pemikiran Klasik Sampai Pemikiran Modern. Yustisia Jurnal Hukum, 3(2). https:// doi.org/10.20961/yustisia.v3i2.11106

Pratiwi, D. K. (2018). Mahkamah Konstitusi Sebagai Negative Legislator Dalam Putusan Mahkamah Konstitusi No. 46/Puu-Xiv/2016 Tentang Uji Materi Pasal Kesusilaan Dalam Kuhp. Literasi Hukum, 2(1), 28-42. https://doi.org/10.1017/ CBO9781107415324.004

Putri, Z. (2018). ICW: Penanganan Korupsi di KPK Naik, Turun di Polri dan Kejaksaan. Detiknews. https:// news.detik.com/berita/d-4217511/icw-penanganan-korupsi-di-kpk-naik-turun-di-polri-dankejaksaan

Soponyono, E. (2012). Kebijakan Perumusan Sistem Pemidanaan yang Berorientasi Pada Korban. Masalah-Masalah Hukum, 41(1), 29-41.

Suparman, F. (2018). ICW: Hukuman Bagi Kepala Daerah Korup Masih Ringan. Berita Satu. https:// www.beritasatu.com/nasional/528035/icwhukuman-bagi-kepala-daerah-korup-masihringan.

Tempo.co. (2019). Bupati Kudus Dua Kali Berurusan dengan Korupsi, Ini Kasusnya. Tempo.Co. https://nasional.tempo.co/read/1229394/bupati-kudus-dua-kali-berurusan-dengan-korupsiini-kasusnya/full\&view $=$ ok

Tim Penulis Buku Pendidikan Anti Korupsi. (2011). Pendidikan Anti Korupsi untuk Perguruan Tinggi (N. T. Puspito, M. Elwina S., I. S. Utari, \& Y. Kurniadi (eds.)). Kementerian Pendidikan dan Kebudayaan RI. 